\title{
Inhibition of Diet-induced Atheroma Formation in Transgenic Mice Expressing Apolipoprotein $E$ in the Arterial Wall
}

\author{
Hitoshi Shimano, Junichi Ohsuga, Masako Shimada, Yoshio Namba, ${ }^{\star}$ Takanari Gotoda, Kenji Harada, Motoya Katsuki, ${ }^{\ddagger}$ \\ Yoshio Yazaki, and Nobuhiro Yamada \\ The Third Department of Internal Medicine, Faculty of Medicine, Tokyo University, 7-3-1 Hongo, Bunkyo-ku, Tokyo, Japan 113; \\ ${ }^{*}$ Department of Neuropathology, Institute of Brain Research, Faculty of Medicine, University of Tokyo, and ${ }^{\ddagger}$ Central Institute for \\ Experimental Animals, 1430 Nogawa, Miyamae, Kawasaki, Japan 213
}

\begin{abstract}
Apolipoprotein E (apoE) plays a crucial role in lipoprotein metabolism both in plasma and in peripheral tissues. To test whether apoE in the vascular wall has a direct and local effect on atherogenesis, we established transgenic mice expressing human apoE under control of $\mathrm{H} 2 \mathrm{Ld}$ promoter. Studies on mRNA levels and immunohistochemistry demonstrated that this line was characterized by high expression of human apoE in the arterial wall while its expression was relatively low in other tissues as compared with the respective endogenous expression of mouse apoE. They showed no difference in plasma cholesterol levels and lipoprotein profile from controls when fed both normal and atherogenic diets. However, after 24 wk of an atherogenic diet, the formation of fatty streak lesions in proximal aorta was markedly inhibited in transgenic mice as compared with controls. Both lesion area and esterified cholesterol content were $<30 \%$ of those in controls. In a tissue cholesterol labeling study with ${ }^{3} \mathrm{H}$-cholesterol, the specific activity of aorta cholesterol was much less in transgenic mice, suggesting that apoE enhances cholesterol efflux from the aortic wall into plasma. Thus, apoE has anti-atherogenic action which is mediated via enhancing reverse cholesterol transport from arterial wall. (J. Clin. Invest. 1995. 95:469-476.) Key words: atherosclerosis - cholesterol - lipoprotein - vascular wall • $\mathrm{H} 2$ antigens
\end{abstract}

\section{Introduction}

Apolipoprotein E (apoE), a major component of plasma lipoproteins, has a high affinity for low density lipoprotein (LDL) receptors and putative chylomicron remnant receptors $(1,2)$. Through its interaction with these receptors mainly in the liver, apoE regulates plasma clearance of lipoproteins containing apolipoprotein B such as very low density lipoprotein (VLDL), intermediate density lipoprotein (IDL), and LDL (3-11). Recently, we have established transgenic mice which overexpress rat apoE in the liver and have high plasma apoE levels (12).

Address correspondence to The Third Department of Internal Medicine, Faculty of Medicine, Tokyo University, 7-3-1 Hongo, Bunkyo-ku, Tokyo, Japan 113. Phone: 3-381-55411; FAX: 3-3392-1870.

Received for publication 24 January 1994 and in revised form 13 September 1994.

J. Clin. Invest.

(C) The American Society for Clinical Investigation, Inc.

0021-9738/95/02/0469/08 $\$ 2.00$

Volume 95, February 1995, 469-476
They showed a marked reduction in plasma lipids due to elimination of plasma VLDL and LDL, and resistance to diet-induced hypercholesterolemia $(13,14)$. In this transgenic line, no fatty streak lesions were found in the aorta after a 10-mo atherogenic diet, while controls exhibited significant lesions (unpublished observation). In contrast, it was reported that apoE deficient mice produced by gene-targeting showed marked increases in VLDL and IDL cholesterol, and developed spontaneous atheromatous lesions in the aorta $(15,16)$. These findings suggest that apoE facilitates plasma clearance of apoB-containing lipoproteins which in the absence of apoE accumulate in plasma as atherogenic lipoproteins and cause atherosclerosis. Meanwhile, we have reported that sustained intravenous injection of apoE inhibited progression of atheroma in Watanabe Heritable Hyperlipidemic rabbits, LDL receptor-deficient animals (17). Interestingly, there was no significant difference at steady state in the plasma cholesterol levels of the apoE injection group and the saline injection group as controls. Thus, the data suggest that a low dose of apoE may inhibit process of atherosclerosis by mechanism(s) other than its plasma cholesterol-lowering activity. In the present study, we intended production of transgenic mice expressing apoE in the arterial wall to see a direct and local effect of apoE on atherogenesis.

\section{Methods}

Materials. pKCR containing mouse $\mathrm{H} 2 \mathrm{Ld}$ promotor was kindly provided by Dr. Miyazaki, J. [1,2,6,7- $\left.{ }^{3} \mathrm{H}(\mathrm{N})\right]$-Cholesterol, $\alpha^{32} \mathrm{P}$-dCTP, and $\gamma^{32}$ P-ATP were purchased from DuPont-New England Nuclear Research Products (Boston, MA). Moloney murine leukemia virus (MMLV) reverse transcriptase was from Promega (Madison, WI). Taq DNA polymerase was from Perkin Elmer Cetus, Roche Molecular Systems, Inc., (Branchburg, NJ). C57BL/6 mice were from Nippon Biosupp. Inc. (Tokyo, Japan). Restriction enzymes were from Boehringer Mannheim GmbH, Biochemica, (Mannheim, Germany). All reagents used were of analytical grade.

Production of transgenic mice. For construction of DNA for microinjection, the SV40 promotor region of the expression vector, pKCR3 (18), was replaced by mouse H2 Ld promotor $(19,20)$. pKCR3 is a pBR322-based plasmid which contains a small portion of second exon, second intron, third exon and 3 ' noncoding region with polyadenylation site of rabbit $\beta$-globin gene (21). Human apoE cDNA (E3) was inserted into EcoRI site in the third exon of rabbit $\beta$-globin gene. The SphI XhoI fragment of the fused plasmid, as represented in Fig. 1, was excised after agarose-electrophoresis, purified by extraction with phenol and chloroform, and used for microinjection. Transgenic mice was produced as previously described (12) except that the fertilized eggs of C57BL/6 were used. Newborn mice were screened for integration of the transgene by polymerase chain reaction (PCR) of tail DNA $(1 \mu \mathrm{g})$ with $5^{\prime}$ primer in $\beta$-globin gene (5'-ACATCCTGGTCATCATCCTG$\left.3^{\prime}\right)(21)$ and $3^{\prime}$ primer in human apoE cDNA (5'-AAAGCGACCCAGTGCCAGTT-3') (22) in 1X PCR buffer (50 mM KCl, $1.5 \mathrm{mM} \mathrm{MgCl}$, $10 \mathrm{mM}$ Tris- $\mathrm{HCl}, \mathrm{pH} 8.3$ ), $100 \mu \mathrm{M}$ dNTPs, and $2 \mathrm{U}$ of Taq polymerase. 


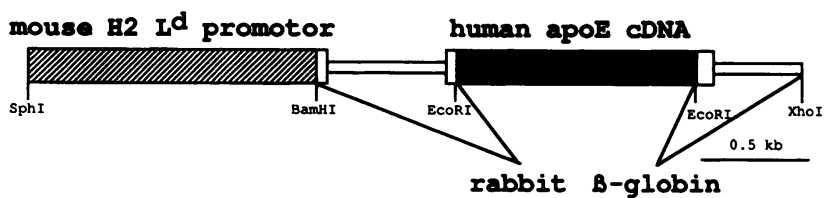

Figure 1. DNA construct for microinjection. The DNA used for microinjection was constructed using expression vector, pKCR3 (18) so that in vivo expression of human apoE cDNA (closed box) would be transcribed under control of mouse $\mathrm{H} 2 \mathrm{Ld}$ promotor (stippled box) (19) with splicing the intron of rabbit $\beta$-globin gene (open boxes). The exons derived from rabbit $\beta$-globin gene are shown as thick open box. The intron and 3' noncoding region containing polyadenylation site are shown as thin open box. This construct was microinjected into fertilized eggs of C57BL/6 to generate transgenic mice.

After the 30th cycling reaction of heat to $94^{\circ} \mathrm{C}$ for 1 min (denature), $63^{\circ} \mathrm{C}$ for $2 \mathrm{~min}$ (anneal), and $72^{\circ} \mathrm{C}$ for $3 \mathrm{~min}$ (extend), the targeted sequence (330 bp) which is specific to the transgene, was amplified. One of the two positive lines was designated as Hae 1-14 and used for the following experiments. By Southern blotting of tail DNA with the probe of human full-length cDNA, the integrated gene was estimated to be ten copy. The inheritance pattern was compatible with a single autosomal integration site.

Preparation of total RNA and blot hybridization with apoE probes. Total RNA was isolated from each tissue of transgenic mice and nontransgenic littermates by extraction with acid guanidinium thiocyanate, phenol and chloroform (23). $1 \mu \mathrm{g}$ of total RNA from arterial walls and $10 \mu \mathrm{g}$ from other tissues were subjected to electrophoresis in a formaldehyde-agarose $(1 \%)$ gel, and transferred to a nylon membrane. The filter was hybridized with a probe of full-length human apoE cDNA labeled by random primer method with $\alpha^{32} \mathrm{P}$-dCTP. As shown in the lanes of liver RNA in Fig. 2, this probe detected both mouse and human apoE mRNA. In some experiments, human apoE-specific oligonucleotide probe ( $5^{\prime}$-ATGGCTGCAGGCTTCGGCGTTCA-3') and mouse apoE-specific oligonucleotide probe (14) were used after $5^{\prime}$ end labeling with $\gamma^{32} \mathrm{P}$-ATP

Differential reverse transcriptased ( $R T)-P C R$. Ratio of human apoE mRNA level to total (human and mouse) apoE mRNA level was estimated by differential RT-PCR method as follows. First strand cDNA was synthesized from $1 \mu \mathrm{g}$ of total RNA from each tissue by incubation at $37^{\circ} \mathrm{C}$ for $60 \mathrm{~min}$ with MMLV reverse transcriptase in $1 \mathrm{X}$ PCR buffer, $200 \mu \mathrm{M}$ dNTPs, $10 \mathrm{mM}$ DTT, RNase inhibitor (2 units) and 20 pmol of the $3^{\prime}$ outer primer (5'-CTTGAGGCGGGCCTGGAA-3'). The mixture was subjected to PCR with 20 pmol of the $5^{\prime}$ primer $\left(5^{\prime}\right.$-TACCTGC GCTGGGTGCAGAC-3') and $3^{\prime}$ inner primer (5'-ACCGCGCTCGGCGCCCTCGCG-3') in 1X PCR buffer, $10 \%$ DMSO, $100 \mu \mathrm{M}$ dNTP with 30 times cycling reaction of heat to $94^{\circ} \mathrm{C}$ for $1 \mathrm{~min}, 60^{\circ} \mathrm{C}$ for 2 min, and $72^{\circ} \mathrm{C}$ for $3 \mathrm{~min}$. This reaction amplified 681-bp fragments derived from both human or mouse apoE cDNA. Since nucleotide sequences of three primers used here were completely identical between human and mouse apoE cDNA $(22,24)$, the relative amounts of target sequences derived from mouse and human apoE mRNAs were the same as those of both original mRNAs. The RT-PCR products derived from human and mouse apoE mRNA could be separated by digestion with Sau3AI whose sites were found only in mouse sequence of the products. The ratios were estimated by comparison of the densities of the bands of the products with or without Sau3AI digestion on $1.5 \%$ agarose after electrophoresis and ethidium bromide staining. The linearity of quantitation under the range of estimation was confirmed by the mixing experiment with total RNA of mouse liver and HepG2 cells as mouse and human apoE mRNA sources, respectively.

Immunohistochemical studies. The heart and attached aorta were resected from transgenic and control mice at $24 \mathrm{wk}$ of age, immersed in saline for $1 \mathrm{~h}$, and immediately fixed in $4 \%$ paraformaldehyde in phosphate buffer saline, pH. 7.4. The paraformaldehyde-fixed, paraffin-

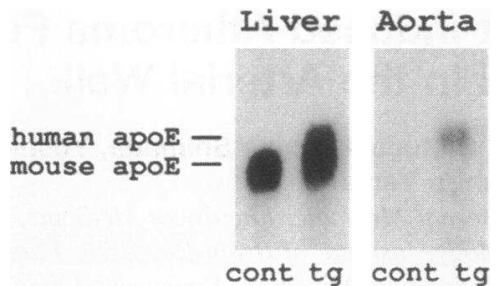

Figure 2. Blot hybridization of total aortic RNA from transgenic mice with human apoE cDNA. Total RNA was isolated from each tissue of transgenic mice $(t g)$ and nontransgenic littermates (cont). In this line, integration of the transgene was confirmed by PCR and Southern blot analyses. $1 \mu \mathrm{g}$ of total RNA from aorta and $10 \mu \mathrm{g}$ of total RNA from liver were subjected to electrophoresis in a formaldehyde-agarose $(1 \%) \mathrm{gel}$, and transferred to a nylon membrane. The filter was hybridized with a probe of human apoE cDNA. As shown in the lanes of liver RNA, this probe detected both mouse and human apoE mRNA. Transgenic and control mice had a similar level of endogenous mouse apoE mRNA, while transgenic mice expressed human apoE mRNA of a slightly longer length from the transgene.

embedded sections of the materials were subjected to immunohistochemistry as previously described (25). The primary antibodies used were a goat anti-human apoE antibody at 1:200. Bound primary antibody was detected by incubation with biotinylated horse anti-goat IgG at 1:200 followed by incubation with peroxidase-conjugated streptavidin.

Atherogenic diet. Female transgenic mice and nontransgenic littermates were housed in the same cages and fed the same diet at the same time. There was no significant difference in the body weights between the transgenic and control groups. For atherogenic diet group, atherogenic diet was given to 11 transgenic and control mice at $12 \mathrm{wk}$ of age. The atherogenic diet contains $15 \%(\mathrm{wt} / \mathrm{wt})$ fat (cocoa butter), $1.25 \%(\mathrm{wt} / \mathrm{wt})$ cholesterol, and $0.5 \%(\mathrm{wt} / \mathrm{wt})$ sodium cholate $(26)$. For normal diet group, normal mouse chow was continued. After 24 wk of the atherogenic diet, blood was drawn from retroorbital plexus to measure plasma cholesterol levels. Animals on the atherogenic diet were sacrificed for evaluation of aortic atheroma.

Estimation of fatty streak lesions in aorta. After the atherogenic diet, the heart and attached aorta were resected, placed in $0.9 \%$ saline for $1 \mathrm{~h}$, and incubated in $7 \%$ formalin for $48 \mathrm{~h}$. After $48 \mathrm{~h}$ in an O.C.T. compound embedding medium, each sample was frozen on a cryostat, and $10-\mu \mathrm{m}$ cross-sections were made beginning with the lower portions of atria. All sections were examined by microscopy without any stain. Four sections, each separated by $60 \mu \mathrm{m}$, were used to evaluate the lesions: two sections at the end of aortic sinus and two sections at the junctional site of the sinus and ascending aorta, which were determined by presence of three valve cusps, and a rounded aorta where the lesions were reproducibly most prominent. Fatty streak lesions were stained by Oil Red $\mathrm{O}$ and haematoxylin. The area of each section was determined by weighing the lesions excised from the enlarged photocopies of a photograph of the section in microscopy. The mean lesion area per section per animal was calculated for each group of animals $(n=6)$.

Measurement of cholesterol content of the aorta. In another set of transgenic and control mice subjected to the atherogenic diet, the heart and attached aorta were resected and placed in $0.9 \%$ saline for $1 \mathrm{~h}$. The heart and surrounding soft tissues were carefully removed. Thoracic and abdominal portions of the aorta were weighed. Lipids were extracted with chloroform/methanol using Folch's method (28). Esterified and unesterified cholesterol contents were measured as described previously (14).

Assays. Plasma cholesterol was measured by enzymatic method (27) and plasma human apoE level was determined by immunoturbid assay. Mouse apoE level of control mice was not detectable by this assay. For determination of cholesterol levels in lipoprotein fraction, a pooled plasma sample from each group was subjected to gel filtration chromatography (HPLC) as previously described (13). Cholesterol levels of each lipoprotein fraction were determined from the area under the curve of monitoring. 

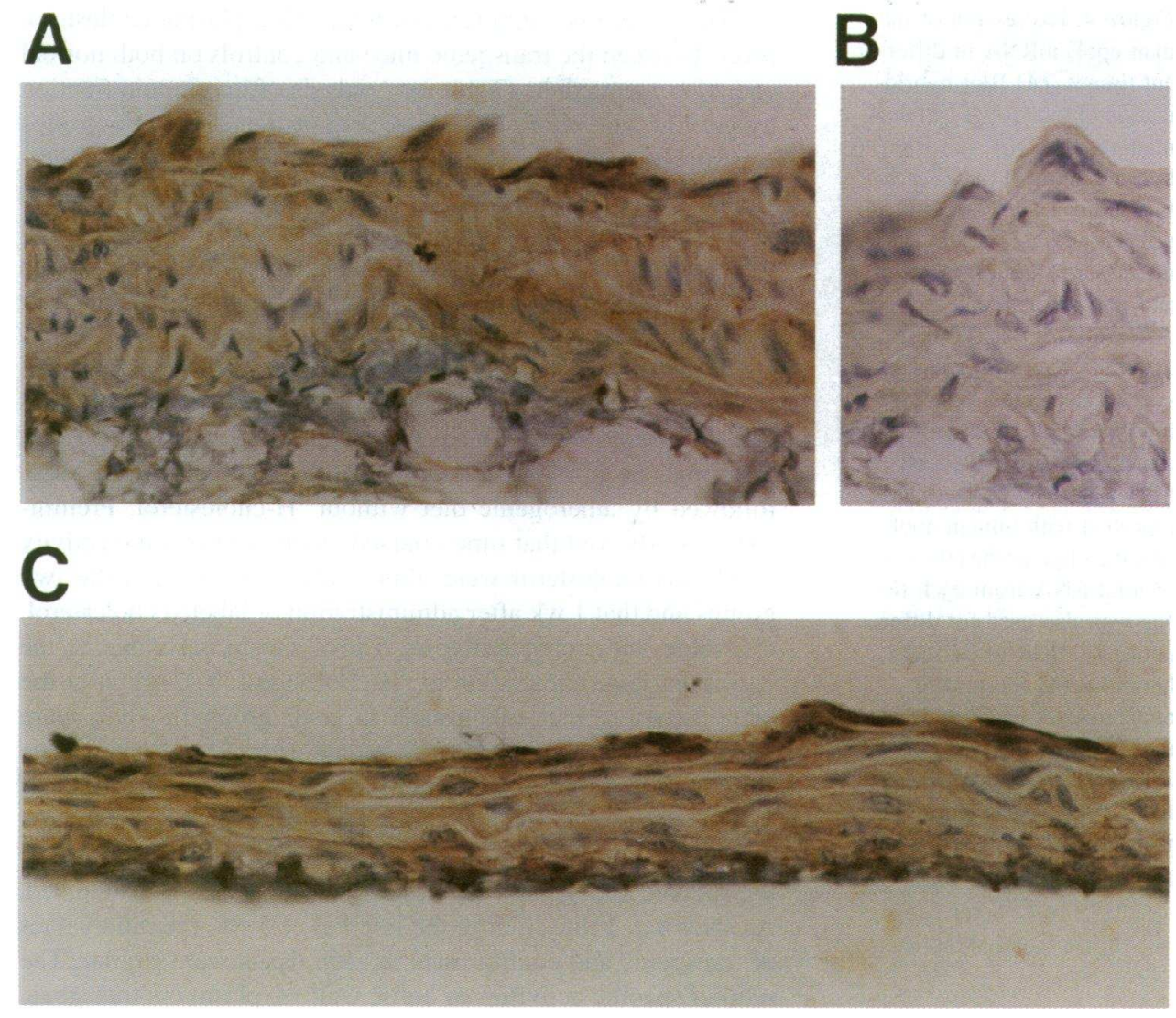

Figure 3. Immunohistochemistry of aortae with anti-human apoE antibody. The heart and attached aorta were resected from transgenic $(A$ and $C$ ) and control mice $(B)$, and were immediately subjected to immunohistochemistry with anti-human apoE polyclonal antibody as described in Methods. $A$ and $B$, cross sections; $C$, longitudinal section. $\times 400$.

Cholesterol labeling study with ${ }^{3} \mathrm{H}$-cholesterol. Transgenic and control mice at 12 weeks of age were given atherogenic diet containing $\left[1,2,6,7-{ }^{3} \mathrm{H}(\mathrm{N})\right]-$-Cholesterol $(1 \mathrm{mCi} / 1 \mathrm{~g}$ cholesterol, $\sim 30 \mu \mathrm{Ci} / \mathrm{mouse})$ for $2 \mathrm{~d}$. Then, the diet was switched to the atherogenic diet without radioisotopes. After three and seven weeks of the atherogenic diet, the animals $(n=7)$ were sacrificed. Blood was drawn and each tissue was resected. Cholesterol was extracted from plasma and each tissue using Folch's method (28). The cholesterol content and radioactivity of each sample were measured. The ratio of specific activity (dpm/ $\mathrm{mg}$ cholesterol) in aorta and other tissues to that in plasma was calculated in each animal.

\section{Results}

In mice, susceptibility to diet-induced atheroma differs in the degree from strain to strain. C57BL/6, which is well known to be most susceptible (29), was used to produce apoE transgenic mice. DNA construct used for microinjection was human apoE (E3) cDNA under control of mouse H2 Ld promotor (Fig. 1). $\mathrm{H} 2 \mathrm{Ld}$, the MHC class I antigen, is expressed ubiquitously in many tissues of mice after late embryonal stage (30). Thus, under control of this promoter, expression of apoE could be expected in arterial wall and the possibility could be excluded that ectopic expression of the transgene might affect organogenesis in embryonal stage. A line, designated HAE 1-14, had 10 copies of the transgene in the estimation of the Southern blot analysis on tail DNA. Northern blot analysis using human apoE cDNA probe demonstrated that human apoE mRNA was found in the aortic wall from transgenic mice (Fig. 2). In contrast, no apoE mRNA was detectable in the aorta from nontransgenic control on this method, although this probe also hybridized mouse apoE mRNA as shown in liver RNA. Immunohistochemistry with anti-human apoE antibody demonstrated that human apoE protein was detected in endothelial cells and medial smooth muscle cells in the aortic wall of the transgenic mice while undetectable in controls (Fig. 3). Furthermore, even in another line of transgenic mice which overexpressed apoE in the liver and not in the artery, and had very high plasma apoE level (12), we could not detect apoE in the artery by the same procedure using rat apoE antibody. Therefore, immunoreactive human apoE in the arterial wall in transgenic mice in this study was produced in situ and not derived from plasma.

On Northern blot analysis using human apoE-specific probe, small, but considerable amounts of human apoE mRNA levels were detected in many other tissues such as liver, lung, spleen, intestine, heart, muscle (Fig. $4 \mathrm{~B}$ ), and peritoneal macrophage (data not shown), which also endogenously express mouse apoE. To estimate human and mouse apoE mRNA levels separately, differential RT-PCR method was developed and relative mRNA levels in each tissue were calculated. As shown in Fig. $4 C$, human apoE mRNA levels in every tissues except arterial wall were relatively low as compared to mouse endogenous levels. By contrast, since the RT-PCR products from aortic wall was almost all derived from human apoE mRNA, the ratio in this tissue was 1.0 , which was consistent with the result from Northern blot analysis (Fig. 2). Consistently, plasma human apoE level of transgenic mice was only $0.85 \mathrm{mg} / \mathrm{dl}$, while mouse apoE levels in both groups were estimated to be $3-4 \mathrm{mg} / \mathrm{dl}$. The ratio of human plasma apoE level to mouse plasma apoE level was in accordance with the mRNA ratio in the liver, which was likely major source of plasma apoE. Furthermore, Northern blot analysis using mouse apoE specific probe which did not 


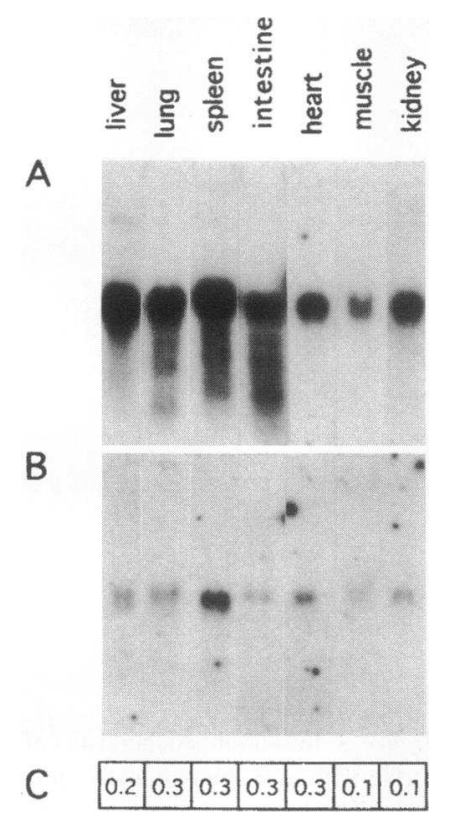

Figure 4. Expression of human apoE mRNA in different tissues. ( $A$ ) Blot hybridization of total RNA with human apoE cDNA. (B) Blot hybridization of total RNA with human apoE specific oligo probe. (C) ApoE mRNA ratio ( human/human and mouse ) estimated by differential RT-PCR. $10 \mu \mathrm{g}$ of total RNA from each tissue was subjected to blot hybridization with human apoE cDNA $(A)$. Thereafter, the filter was dehybridized and reprobed with human apoE specific oligo probe $(B) .1 \mu \mathrm{g}$ of total RNA from each tissue was also used for differential RT-PCR to estimate human apoE and mouse apoE mRNA levels separately. Ratio of human apoE mRNA level to total (human and mouse endogenous) mRNA level in each tissue was shown $(C)$. The values were obtained from two independent experiments using six animals. The value in aortic wall was 1.0 since almost all RT-PCR product was derived from human apoE mRNA.

hybridize with human apoE mRNA showed that mouse apoE mRNA level in each mouse apoE-expressing tissue was not significantly different between transgenic and control mice (data not shown). These data indicate that this line expresses human apoE characteristically in the arterial wall, and that, in other tissues and in plasma, apoE expression was similar to control mice. Thus, it could be concluded that this line was a good model for evaluation of local function of apoE in the arterial wall.

For analysis of diet-induced atheroma, atherogenic diet containing high cholesterol and fat was given to transgenic mice and non-transgenic controls. After 24 wk, proximal aortic sections were stained with Oil-red $\mathrm{O}$ and formation of fatty streak lesions were compared. Representative microscopies of the lesions were shown in Fig. 5. The fatty streak lesions were much smaller (30\% in area) in transgenic mice than in controls (Fig. 6). As shown in Fig. 5, the lesions were found in both aortic wall and valve cusps. Fatty streak lesions in cusps were reported not to be correlated to those in arterial walls, not to be reproducible, and thus recommended to be excluded from estimation (31). When the lesions under consideration were restricted to aortic walls and did not include valve cusps, the difference in lesion area was much more prominent (15\% of controls) since the lesions in cusps were similar between the two groups (Fig. 6). The contents of cholesterol in whole thoracic and abdominal portions of aorta were measured (Fig. 7). The esterified cholesterol content was much less in transgenic mice than in controls, while there was no significant difference in the total cholesterol content. The data indicated that apoE expressed in the arterial wall had an inhibitory effect on formation of diet-induced early atherosclerosis. Qualitative aspects of the fatty streak lesions in aortic wall, such as foamy macrophages, were similar between the two groups.
There were no significant differences in plasma cholesterol levels between the transgenic mice and controls on both normal and atherogenic diets (Table I). Analysis of lipoprotein fraction by gel filtration chromatography demonstrated that two groups had similar patterns of lipoprotein cholesterol profile. The atherogenic diet caused a marked increase in non-HDL (VLDL and LDL) cholesterol and a profound decrease in HDL cholesterol in both groups. Thus, the inhibitory effect of apoE on the formation of fatty streak lesions in transgenic mice was not attributed to plasma cholesterol level and profile.

To know the mechanism by which transgenic mice have smaller fatty streak lesions, efflux of cholesterol from arterial wall to plasma was estimated. ${ }^{3} \mathrm{H}$-cholesterol was orally given to animals on atherogenic diet for $\mathbf{2} \mathrm{d}$ to label tissue cholesterol, followed by atherogenic diet without ${ }^{3} \mathrm{H}$-cholesterol. Preliminary data showed that time-coursed changes in specific activity of plasma cholesterol were almost identical between the two groups and that $1 \mathrm{wk}$ after administration of labeled cholesterol, the value was decreased to $<5 \%$ of the initial value at the cessation of administration of ${ }^{3} \mathrm{H}$-cholesterol. 3-7 wk after the administration, half of animals in each group $(n=7)$ were sacrificed and specific activities of cholesterol in plasma, aortic wall and other tissues were measured. To exclude variations of data among animals of each group mainly because of differences in intestinal absorption of radiolabeled cholesterol, the ratio of the specific activity in each tissue vs. in plasma was calculated. As shown in Table II, after the interval of $3 \mathrm{wk}$, the ratio values of transgenic and control mice in each tissue were similar. The ratio of specific activities of aortic wall vs. plasma in transgenic and control mice were $<1.0$ while the values of the two groups in other tissues were 1.0 or more, suggesting that incorporation of labeled cholesterol from plasma into aortic wall was relatively slow as compared to those into other tissues. This was consistent with previous report on the tissue cholesterol labeling studies with rabbits (32) 7 wk after the administration, when the specific activities in aortic walls of both groups were higher than those in plasma, the ratio of aortic wall vs. plasma was significantly lower in transgenic mice than in controls ( $P$ $<0.05$ ). The data suggest that cholesterol efflux from aorta was enhanced in transgenic mice. At this interval, other tissues in transgenic mice also had lower ratios than in controls, although not significant.

Immunohistochemical staining of apoE in the aortic sinus from transgenic mice after the atherogenic diet was shown in Fig. 8. Marked staining of apoE was found in the advanced atheromatous lesions (Fig. $8 \mathrm{~A}$ ) as well as apparently normal area of arterial wall (Fig. $8 \mathrm{~B}$ ). Immunoreactive apoE in the lesions was localized mainly in the extracellular matrix.

\section{Discussion}

Since apoE was found in the atheromatous lesions, it has been thought to be involved in atherogenesis (33-35). Our present data suggest that apoE localized in the arterial wall has antiatherogenic function. While apoE expression under control of Ld promotor in this transgenic mice was found ubiquitously in many tissues, the difference between the transgenic and control groups was only prominent in arterial wall. Thus, this line is a good model for analysis on the effects of apoE produced locally in the arterial wall.

Dramatic inhibition of diet-induced atheroma was demonstrated in transgenic mice. Diet-induced atheroma in mice has 


\section{Control}

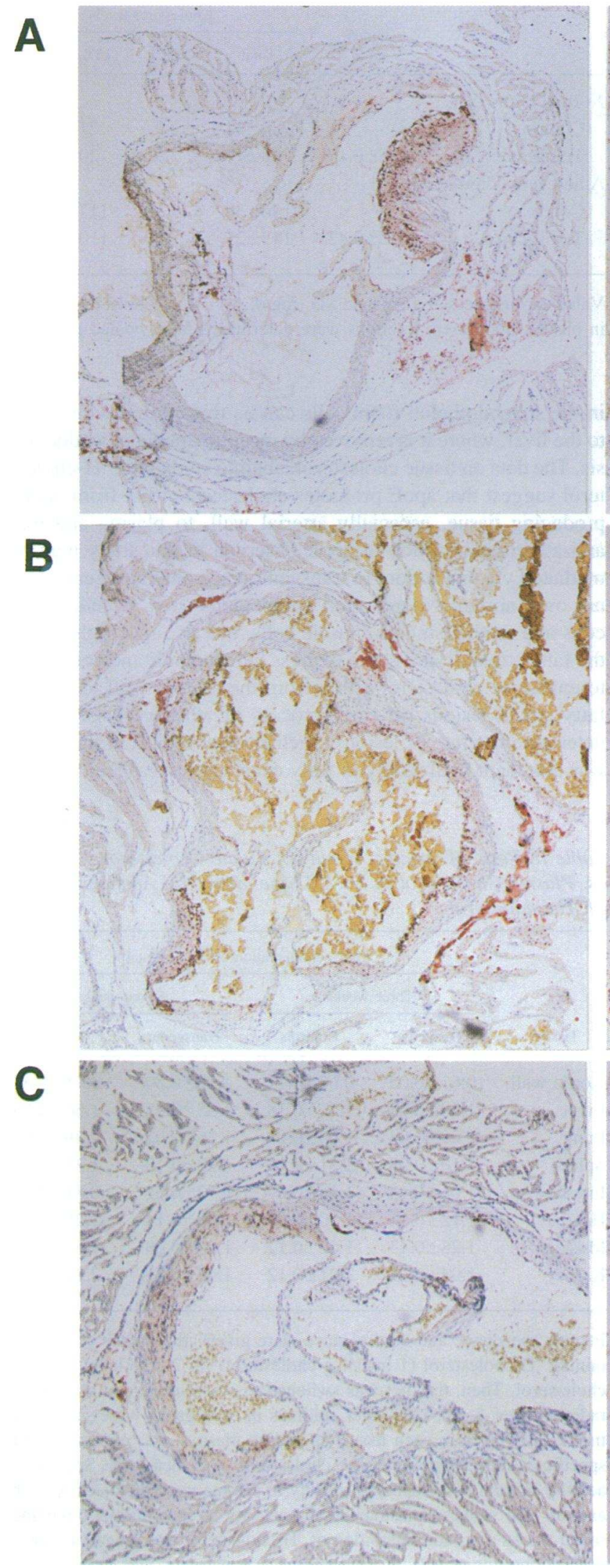

\section{Transgenic}
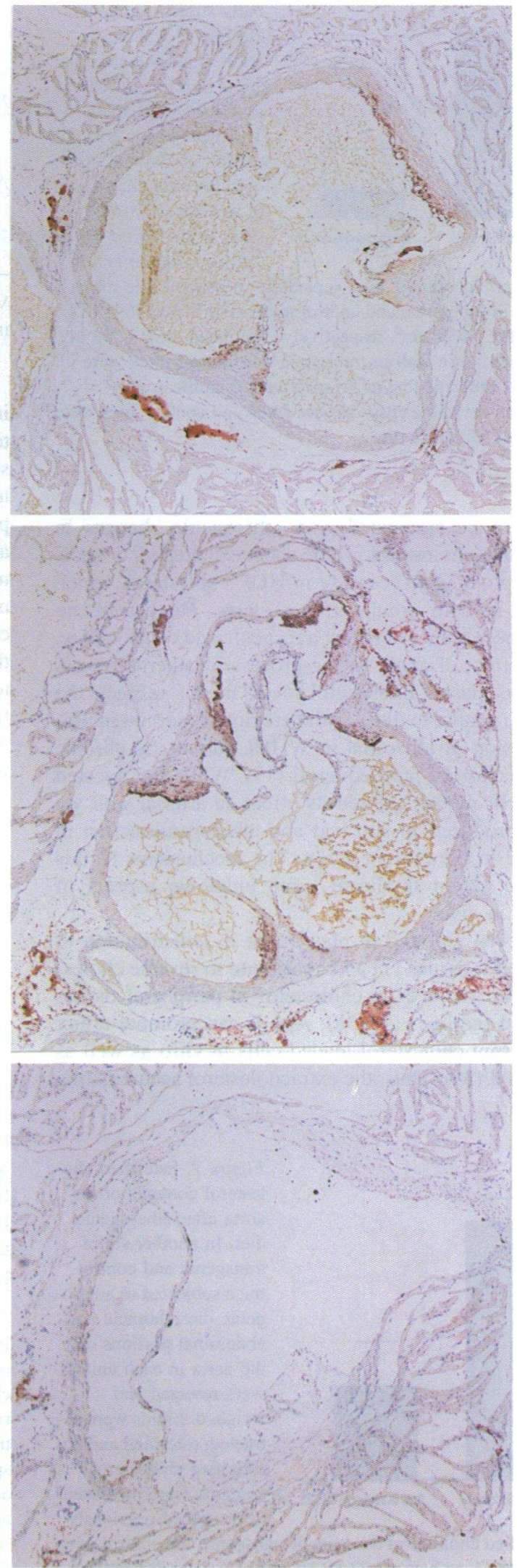

Figure 5. Fatty streak lesions in proximal aorta and aortic sinus after atherogenic diet. After $24 \mathrm{wk}$ of atherogenic diet, the hearts and aortae of transgenic mice and nontransgenic littermates were resected for evaluation of fatty streak lesions. Representative microscopies of the three different cross sections after Oil Red $O$ and haematoxylin staining are shown: the aortic sinus $(B$ and $C)$ and the junctional site of aortic sinus and proximal aorta $(A) . \times 140$. 


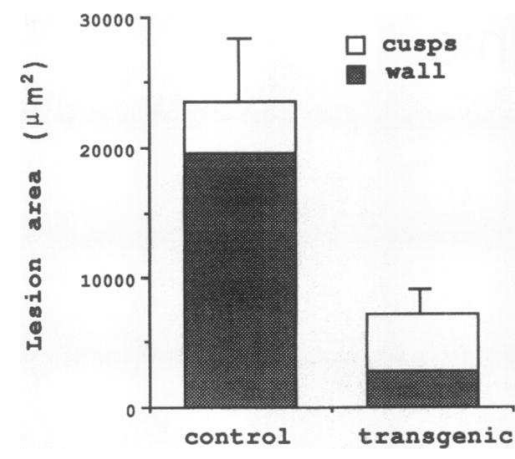
the valve cusps (open column) were separately measured. The mean total lesion areas in transgenic and control mice were $7130 \pm 1692$ (S.D. as bars) and $23460 \pm 6639 \mu \mathrm{m}^{2}$, respectively (significant at $P<0.001$ ). Lesion areas in the aortic wall in transgenic and control mice were $2876 \pm 1904$ and $19580 \pm 6145 \mu \mathrm{m}^{2}$, respectively (significant at $P$ $<0.001$ ). Those in the valve cusps in transgenic and control mice were $3879 \pm 1430$ and $4253 \pm 1682 \mu \mathrm{m}^{2}$.

been reported to be associated with atherogenic changes in plasma lipoprotein cholesterol profile such as increases in apoB containing lipoproteins or decrease in HDL cholesterol, which were observed in both groups in this study. There were no differences in these values between transgenic and control mice, therefore, the effect of apoE on the process of atherosclerosis is not related to plasma cholesterol level. In this respect, the observations are similar to those in the previous report on inhibition of progression of atheroma in WHHL rabbits by chronic intravenous injection of purified apoE (17). While the injected apoE into WHHL rabbits exerted its effect on arterial wall via plasma, apoE produced in situ had anti-atherogenic action in transgenic mice in the current study. The mechanisms of this anti-atherogenic action implicate some unknown aspects of apoE functions in vivo.

ApoE has been reported to play a role in redistribution of lipids in peripheral tissues (1) and contribute to reverse cholesterol transport in which extra-cholesterol in peripheral tissues is transported to the liver (36-38). Apo E can promote efflux of cholesterol from cholesterol-loaded cells in vitro as well as apolipoprotein AI (39). Thus, the extracholesterol accumulating

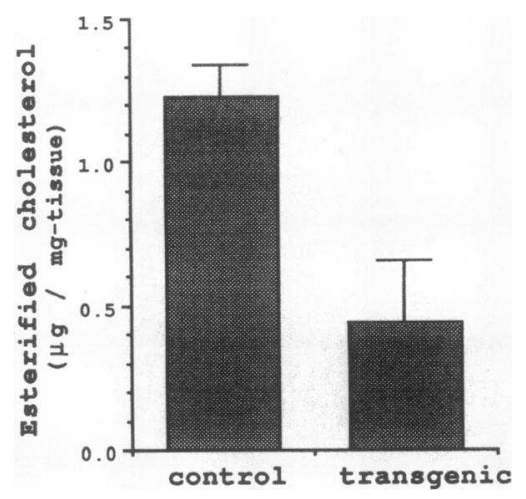

Figure 7. Esterified cholesterol contents of the aorta after atherogenic diet. In another set of transgenic and control mice subjected to atherogenic diet, thoracic and abdominal portions of the aorta in each animal were resected and weighed. Lipids were extracted, esterified and unesterified cholesterol contents were measured as described previously

(12). Mean esterified cholesterol contents of transgenic and control mice were $0.44 \pm 0.22$ (S.D. as bars), $1.23 \pm 0.10 \mu \mathrm{g} / \mathrm{mg}$-tissue, respectively (significant at $P<0.05, n=5$ ). Unesterified cholesterol contents were $5.50 \pm 0.74,5.22 \pm 0.56 \mu \mathrm{g} / \mathrm{mg}$-tissue, respectively.
Table I. Plasma Cholesterol Profile in Transgenic and Control Mice

\begin{tabular}{lccccc}
\hline & & \multicolumn{4}{c}{ Cholesterol levels } \\
\cline { 3 - 6 } & $\begin{array}{c}\text { Human } \\
\text { apoE }\end{array}$ & Total & VLDL & LDL & HDL \\
\hline Normal chow diet & & & & & \\
$\quad$ Controls & - & $86 \pm 11$ & 2.9 & 21 & 62 \\
$\quad$ Transgenics & $0.85 \pm 0.17$ & $85 \pm 11$ & 2.9 & 20 & 62 \\
Atherogenic diet & & & & & \\
$\quad$ Controls & - & $146 \pm 39$ & 9.1 & 117 & 20 \\
$\quad$ Transgenics & $1.2 \pm 0.43$ & $142 \pm 25$ & 7.0 & 110 & 25 \\
& & & & & \\
\hline
\end{tabular}

Values are expressed as mean $\pm \mathrm{SD}(\mathrm{mg} / \mathrm{dl}, n=11)$. Cholesterol levels in plasma lipoprotein fractions were determined from pooled plasma.

in the subendothelial foam cells can be transported with apo $\mathrm{E}$ to the liver, where it is removed by receptor-mediated endocytosis. The data on tissue cholesterol labeling study with ${ }^{3} \mathrm{H}$-cholesterol suggest that apoE promotes cholesterol efflux from apoEproducing tissue, especially arterial wall, to plasma and that anti-atherogenic action of apoE observed in this study may be mediated via this action. In transgenic mice on atherogenic diet, not only normal vascular cell components such as endothelial cells and medial smooth muscle cells, but also macrophages in the fatty streak lesion could express human apoE and contribute to enhanced cholesterol efflux from the arterial wall to protect fatty streak lesions. In early process of atherogenesis, it may determine the fate of lesions whether or not apoE in the lesion was abundant sufficiently to fully exert anti-atherogenic action

Table II. Ratio of Specific Activity of Tissue Cholesterol vs. Plasma Cholesterol in Each Tissue after Oral Administration of ${ }^{3} \mathrm{H}$-Cholesterol

\begin{tabular}{|c|c|c|c|c|}
\hline \multirow[b]{3}{*}{ Tissue } & \multicolumn{4}{|c|}{ After administration of ${ }^{3} \mathrm{H}$-cholesterol } \\
\hline & \multicolumn{2}{|c|}{ Three weeks } & \multicolumn{2}{|c|}{ Seven weeks } \\
\hline & Transgenics & Controls & Transgenics & Controls \\
\hline Aortic wall & $0.61 \pm 0.05$ & $0.65 \pm 0.11$ & $1.98 \pm 0.80^{*}$ & $3.75 \pm 0.60$ \\
\hline Liver & $1.60 \pm 0.08$ & $1.62 \pm 0.18$ & $1.55 \pm 0.21$ & $1.50 \pm 0.05$ \\
\hline Lung & $1.09 \pm 0.04$ & $1.00 \pm 0.03$ & $1.26 \pm 0.02$ & $1.39 \pm 0.08$ \\
\hline Spleen & $1.10 \pm 0.08$ & $1.31 \pm 0.13$ & $1.22 \pm 0.10$ & $1.37 \pm 0.17$ \\
\hline Intestine & $1.06 \pm 0.14$ & $1.13 \pm 0.09$ & $0.72 \pm 0.02$ & $0.81 \pm 0.04$ \\
\hline Heart & $1.12 \pm 0.16$ & $1.10 \pm 0.09$ & $1.08 \pm 0.14$ & $1.25 \pm 0.01$ \\
\hline Muscle & $1.28 \pm 0.13$ & $1.62 \pm 0.12$ & $1.46 \pm 0.09$ & $1.67 \pm 0.16$ \\
\hline Kidney & $1.94 \pm 0.21$ & $2.21 \pm 0.12$ & $1.57 \pm 0.31$ & $2.21 \pm 0.31$ \\
\hline
\end{tabular}

Female transgenic and control mice were given atherogenic diet containing ${ }^{3} \mathrm{H}$-cholesterol $(1 \mathrm{mCi} / 1 \mathrm{~g}$ cholesterol) for $2 \mathrm{~d}$ to label tissue cholesterol. Then, the diet was switched to atherogenic diet without radioisotopes. 3 and $7 \mathrm{wk}$ later, animals in each group were sacrificed, tissue cholesterol in each tissue (including plasma) was extracted, and specific activity (dpm/mg-tissue cholesterol) was measured. Specific activity in each tissue/specific activity in plasma was calculated in each animal. The value of plasma specific activity in each animal three and seven weeks after administration of ${ }^{3} \mathrm{H}$-cholesterol was ranged 46,400 $80,500 \mathrm{dpm} / \mathrm{mg}, 4,100-7,200 \mathrm{dpm} / \mathrm{mg}$, respectively, and showed no significant difference between transgenic and control mice. Values are expressed as mean \pm SE, $n=7 . \quad * P<0.05$ as compared with controls. 
A

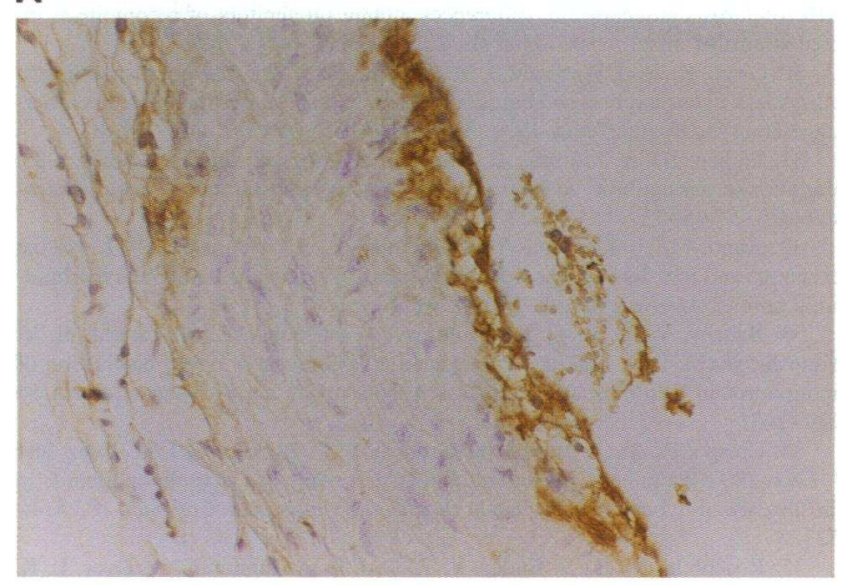

B

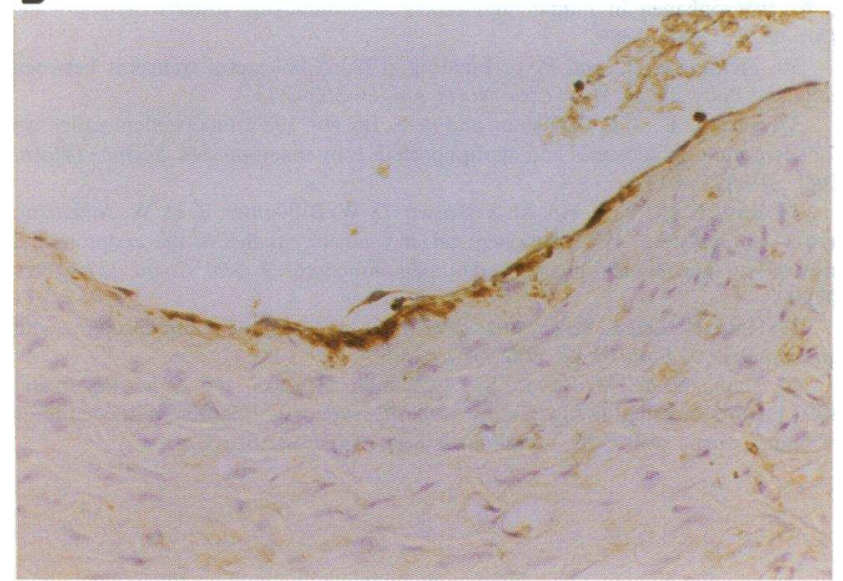

Figure 8. Presence of immunoreactive apoE in aorta from transgenic mice after atherogenic diet. Some sections of aortic sinus from transgenic mice after $24 \mathrm{wk}$ of atherogenic diet were immunostained with anti-human apoE antibody. Adjacent section was stained with OilRed $O$. Fatty streak lesions were obvious in the intima in $A$ and minimal in $B . \times 400$.

Extracellular presence of apoE in the atheroma (33 35) might be resultant remnants of protective reaction against atherosclerosis rather than a causative agent. Since other tissues which expressed human apoE also tended to slightly increase cholesterol efflux to plasma, there might be some quantitative correlation between expression of apoE and cholesterol efflux, and enhanced cholesterol efflux by apoE expression may be universal among various tissues. Although not statistically significant, there tended to be slightly higher plasma HDL cholesterol level in transgenic mice on atherogenic diet than in controls (Table I). This may reflect the enhanced efflux of cholesterol in transgenic mice.

It is also possible that apoE in the arterial wall could modulate some steps in atherogenesis and modulate the atherogenesis by mechanisms other than enhanced cholesterol efflux. ApoE might affect recruitment of plasma monocytes into the initial lesion of atheroma to form foamy macrophages (40). Furthermore, since apoE was proposed to play a role in proliferation and differentiation of lymphocytes and smooth muscle cells, presence of apoE in the arterial wall might inhibit atherosclero- sis by modulating the cellular functions of these cell components of atherosclerosis (1).

The current study demonstrated that apoE produced locally in the aortic wall enhanced reverse cholesterol transport and protected the aorta from diet-induced early atherosclerosis. This suggests that apoE could be a new therapeutic agent which acts not only systemically against hyperlipidemia, but also locally against atherosclerosis.

\section{Acknowledgments}

We are grateful to Dr. E. M. Rubin. for useful technical advices for atherogenic diet.

\section{References}

1. Mahley, R. W. 1988. Apolipoprotein E: cholesterol transport protein with expanding role in cell biology. Science (Wash. DC). 240:622-630.

2. Brown, M. S., and J. L.Goldstein. 1986. A receptor pathway for cholesterol homeostasis. Science (Wash. DC). 232:4-37.

3. Pitas, R. E., T. L. Innerarity, K. S. Arnold, and R. W. Mahley. 1979. Rate and equilibrium constants for binding of apo-E HDLc (a cholesterol-induced lipoprotein) and low density lipoproteins to human fibroblasts: Evidence for multiple receptor binding of apo-E HDLc. Proc. Natl. Acad. Sci. USA. 76:2311-2315.

4. Yamada, N., D. M. Shames, J. B. Stoudmire, and R. J. Havel. 1986 Metabolism of lipoproteins containing apolipoprotein B-100 in blood plasma of rabbits: Heterogeneity related to the presence of apolipoprotein E. Proc. Natl. Acad. Sci. USA. 83:3479-3483.

5. Yamada, N., D. M. Shames, and R. J. Havel. 1987. Effect of low density lipoprotein receptor deficiency on the metabolism of apolipoprotein B-100 in blood plasma. J. Clin. Invest. 80:507-515.

6. Yamada, N., D. M. Shames, K. Takahashi, and R. J. Havel. 1988. Metabolism of apolipoprotein B-100 in large very low density lipoproteins of blood plasma. J. Clin. Invest. 82:2106-2113.

7. Eisenberg, S., G. Friedman, and T. Vogel. 1988. Enhanced metabolism of normolipidemic human plasma very low density lipoprotein in cultured cells by exogenous apolipoprotein E-3. Arteriosclerosis 8:480-487.

8. Yamada, N., H. Shimano, H. Mokuno, S. Ishibashi, T. Gotohda, M. Kawakami, Y. Watanabe, Y. Akanuma, T. Murase, and F. Takaku. 1989. Increased clearance of plasma cholesterol after injection of apolipoprotein $\mathrm{E}$ into Watanabe heritable hyperlipidemic rabbits. Proc. Natl. Acad. Sci. USA. 86:665-669.

9. Mahley, R. W., K. H. Weisgraber, M. M. Hussain, B. Greenman, M. Fisher, T. Vogel, and M. Gorecki. 1989. Intravenous infusion of apolipoprotein $\mathrm{E}$ accelerates clearance of plasma lipoproteins in rabbits. J. Clin. Invest. 83:21252130.

10.Mokuno, H., N. Yamada, H. Shimano, S. Ishibashi, N. Mori, K. Takahashi, T. Oka, T. H. Yoon, and F. Takaku. 1991. The enhanced cellular uptake of verylow-density lipoprotein enriched in apolipoprotein E. Biochim. Biophys. Acta. 1082:63-70.

11. Shimano, H., C. Fukazawa, Y. Shibasaki, N. Mori, T. Gotoda, K. Harada, M. Shimada, N. Yamada, Y. Yazaki, and F. Takaku. 1991. The effect of apo E secretion on lipoprotein uptake in transfected cells. Biochim. Biophys. Acta. 1086:245-254.

12. Shimano, H., N. Yamada, M. Shimada, N. Ohsawa, C. Fukazawa, Y Yazaki, F. Takaku, and M. Katsuki. 1991. Hepatic and renal expression of rat apolipoprotein $E$ under control of the metallothionein promotor in transgenic mice. Biochim. Biophys. Acta. 1090:91-94.

13. Shimano, H., N. Yamada, M, Katsuki, M Shimada, T. Gotoda, K. Harada, T Murase, C. Fukazawa, F. Takaku, and Y. Yazaki. 1992. Overexpression of apolipoprotein $\mathrm{E}$ in transgenic mice: a marked reduction in plasma lipoproteins except high density lipoprotein, and resistance against diet-induced hypercholesterolemia. Proc. Natl. Acad. Sci. USA. 89:1750-1754.

14. Shimano, H., N. Yamada, M. Katsuki, K. Yamamoto, T. Gotoda, K. Harada, M. Shimada, and Y. Yazaki. 1992 Plasma lipoprotein metabolism in transgenic mice overexpressing apolipoprotein E: Accelerated clearance of lipoproteins containing apolipoprotein B. J. Clin. Invest. 90:2084-2091.

15. Zhang, S. H., R. L. Reddick, J. A. Pierdrahita, and N. Maeda. 1992 Spontaneous hypercholesterolemia and arterial lesions in mice lacking apolipoprotein E. Science (Wash. DC). 258:468-471.

16. Plump, A. S, J. D. Smith, T. Hayek, K. Aalto-Setala, A. Walsh, J. G. Verstuyft, E. M. Rubin, and J. L. Breslow. 1992. Severe hypercholesterolemia and atherosclerosis in apolipoprotein E-deficient mice created by homologous recombination in ES cells. Cell. 71:343-353.

17. Yamada, N., I. Inoue, M. Kawamura, K. Harada, Y. Watanabe, H. Shimano, T. Gotoda, M. Shimada, K. Kozaki, T. Tsukada, M. Shiomi, Y. Watanabe, 
and Y. Yazaki. 1992. Apolipoprotein E prevents the progression of atherosclerosis in WHHL rabbits. J. Clin. Invest. 89:706-711.

18. Landais, D., B. N. Beck, J.-M. Buerstedde, S. Degraw, D. Klein, N. Koch, D. Murphy, M. Pierres, T. Tada, K. Yamamoto, C. Benoist, and D. Mathis. 1986. The assignment of chain specificities for anti-Ia monoclonal antibodies using $\mathbf{L}$ cell transfectants. J. Immunol. 137:3002-3005.

19. Evans, G. A., D. H. Margulies, B. Shykind, J. G. Siedman, and K. Ozato. 1982 Exon shuffling: domain structure defines polymorphic determinants of $\mathrm{H}-2$ transplantation antigen. Nature (Lond.). 300:755-757.

20. Sugita, K., J. Miyazaki, E. Appella, and K. Ozato Mol.Cell Biol. 1987. Interferons increase transcription of a major histocompatibility class I gene via a $5^{\prime}$ interferon consensus sequence. 7:2625-2630.

21. van Ooyen, A., J. van den Berg., N. Mantei, and C. Weissmann. 1979. Comparison of total sequence of a cloned rabbit $\beta$-globin gene and its flanking regions with a homologous mouse sequence. Science (Wash. DC). 206:337-344.

22. Breslow, J. L., J. McPherson, A. L. Nussbaum, H. W. Williams, F. Lofquist-Kahl, S. K. Karathanasis, and V. I. Zannis. 1983. Identification and DNA sequence of a human apolipoprotein cDNA. J. Biol. Chem. 257:14639-14641.

23. Chomczynski, P., and N. Sacchi. 1987. Single-step method of RNA isolation by acid guanidinium thiocyanate-phenol-chloroform extraction. Anal. Biochem. 162:156-159.

24. Rajavashissth,T. B., J. S. Kaptein, K. L. Reue, and A. J. Lusis. 1985 Evolution of apolipoprotein E:Mouse sequence and evidence for an 11-nucleotide ancestral unit. Proc. Natl. Acad. Sci. USA. 82:8085-8089.

25. Shimano,H., Y. Namba, , J. Ohsuga,, M. Kawamura, K. Yamamoto, M. Shimada, T. Gotoda, K. Harada, Y. Yazaki, and N. Yamada. 1994. Secretionrecapture process of apolipoprotein $\mathrm{E}$ in hepatic uptake of chylomicron remnants in transgenic mice. J. Clin. Invest. 93:2215-2223.

26. Rubin, E. M., R. M. Krauss, E. A. Spangler, J. G. Verstuyft, and S. M. Clift. 1991. Inhibition of early atherogenesis in transgenic mice by human apolipoprotein AI. Nature (Lond.). 353:265-267.

27. Allain, C. C., L. S. Poon, C. S. G. Chan, W. Richmond, and P. C. Fu 1974. Enzymatic determination of total serum cholesterol. Clin Chem. 20:470475 .

28. Folch, J., M. Lees, and G. H. Sloane-Stanley. 1957. A simple method for the isolation and purification of total lipids from animal tissues. J. Biol. Chem. 226, 497-509.
29. Paigen, B., B. Y. Ishida, J. Verstuyft, R. B. Winter, and D. Albee. 1990 Atherosclerosis susceptibility differences among progenitors of recombinant inbred strains of mice. Arteriosclerosis, 10:316-323.

30. Ozato, K., Y.-J. Wan, and B. M. Orrison. 1985. Mouse major histocompatibility class I gene expression begins at midsomite stage and is inducible in earlierstage embryos by interferon. Proc. Natl. Acad. Sci. USA. 82:2427-2431.

31. Paigen, B., A. Morrow, C. Brandon, D. Mitchell, and P. Holmes 1985. Variation in susceptibility to atherosclerosis among inbred strains of mice. Atherosclerosis. 57:65-73.

32. Kano, M., J. Koizumi, A. Jadhav, and G. R. Thompson. 1987. Plasma exchange and low density lipoprotein apheresis in Watanabe heritable hyperlipidemic rabbits. Arteriosclerosis. 7:256-261.

33. Babaev, V. R., A. D. Dergunov, A. A. Chenchik, E. M. Tararak, E. V. Yanushevskaya, I. N. Trakht, C. Sorg, and V. N.Smirnov. 1990 Localization of apolipoprotein $\mathrm{E}$ in normal and atherosclerotic human aorta. Atherosclerosis. 85 239-247.

34. Crespo, P., M. A. Ros, J. M. Ordovas, J. C. Rodriguez, J. M. Ortiz, and J. Leon 1992 Foam cells from aorta and spleen overexpress apolipoprotein E in the absence of hypercholesterolemia. Biochem. Biophys. Res. Commun. 183:514523.

35. Rosenfeld, M. E., S. Butler, V. A. Ord, B. A. Lipton, C. A. Dyer, L. K. Curtiss, W. Palinski, and J. L. Witztum. 1993. Abundant expression of apoprotein $\mathrm{E}$ by macrophages in human and rabbit atherosclerotic lesions. Arterioscler. Thromb. 13:1382-1389.

36. Fielding,C. J., and P. E. Fielding. 1982. Cholesterol transport between cells and body fluids. Med. Clin. North Am. 66:363-373.

37. Basu, S. K., J. L. Goldstein, and M. S. Brown. 1983. Independent pathways for secretion of cholesterol and apolipoprotein E by macrophages. Science (Wash DC). 219:871-873.

38. Basu, S. K., Y. K. Ho, M. S. Brown, D. W. Bilheimer, R. G. W. Anderson, and J. L. Goldstein. 1982. Biochemical and genetic studies of the apoprotein E secreted by mouse macrophages and human monocytes. J. Biol. Chem. 257:97889795.

39. Hara, H., and S. Yokoyama. 1991. Interaction of free apolipoproteins with macrophages J. Biol. Chem. 266:3080-3086.

40. Hama, S. Y., M. Navab, S. D. Cushing, H. Laks, and A. M. Fogelman 1993 Factors modulating the modification of low density lipoprotein in cocultures of human aortic wall cells. Circulation. 88:I-33:0162 (Abstr.). 